DOI: $10.1515 /$ plass-2015-0029

Mariana Petkova ${ }^{1}$, Wun S. Chao ${ }^{2}$, Leonard Cook ${ }^{2}$, Mark West ${ }^{3}$, Mukhlesur Rahman ${ }^{4}$, Michael E. Foley ${ }^{2}$

\author{
${ }^{1}$ Agriculture University-Plovdiv, 400012 Mendeleev Blvd., Bulgaria; ${ }^{2}$ USDA-Agricultura \\ Research Service, 1605 Albrecht Blvd., Fargo, ND 58102 USA; ${ }^{3}$ USDA-Agricultural \\ Research Service, 2150 Centre Ave., Bldg. D, Suite 300, Fort Collins, CO 80526 USA; \\ ${ }^{4}$ North Dakota State University, Department of Plant Sciences, P.O. Box 6050, \\ Fargo, ND 58108 USA; michael.foley@ars.usda.gov

\section{FATTY ACID AND TRANSCRIPT PROFILING IN DEVELOPING SEEDS OF THREE BRASSICA NAPUS CULTIVARS}

\begin{abstract}
Fatty acid levels and gene expression profiles for selected genes associated with the synthesis of fatty acids (FA), triacylglycerol, and oil body proteins were examined in three oilseed rape (Brassica napus) cultivars that have utility for cultivar development in our spring canola breeding program. The seed oil content of Bronowski, Q2, and Westar was 39.0, 40.1, and 40.6\%, respectively at 40 days after flowering (DAF). During the 20 to 40 day period of seed development, cultivars had varying levels of palmitic, stearic, oleic, linoleic, $\alpha$ -linolenic, eicosenoic, and erucic acid. In general, the percentage of each FA was similar among the cultivars during seed development. However, the level of oleic acid was lower and the levels of eicosenoic acid and erucic acid were higher in Bronowski than in Q2 and Westar seeds; linoleic acid also tended to be lower in Bronowski. Gene expression among the cultivars was similar from 10 to $40 \mathrm{DAF}$. The few exceptions were that expression of $K A S 1$ and $S A D$ were higher in Westar and Q2 than in Bronowski at 25 DAF, $S A D$ was highest in Q2, intermediate in Westar, and lowest in Bronowski at 35 DAF, FAD2 was higher in Q2 than in Bronowski at 35 DAF, FAD3 was higher in Q2 than in Bronowski at 15 DAF and Q2 and Westar at 25 and 30 DAF, and FAE1 was higher in Westar and Q2 than in Bronowski at 30 DAF. Correlation analysis for gene expression against DAF for each genotype supported a common trend in gene expression among the three cultivars with gene expression tending to decrease over time; except for $L P A A T$, which tended to increase. The correlation between the level of FAs and expression of genes by genotype indicated no general trend; rather correlations seem to depend on the genotype.
\end{abstract}

Key words: Brassica napus, canola, fatty acid, gene expression, oilseed, rapeseed, seed.

Communicated by Grzegorz Żurek 
Marina Petkova et al...

\section{INTRODUCTION}

Brassica napus (L.) is commonly referred to as canola, rapeseed, or oilseed rape. Canola itself was bred from rapeseed in Canada to develop a nutritious oil low in glucosinolates and erucic acid (Stefansson et al. 1961; Stefansson and Kondra 1970), which are anti-nutritional components for humans and livestock. Canola is the second largest vegetable oilseed crop worldwide behind soybean (http://www.ers.usda.gov/data-products/oil-crops -yearbook.aspx). The U.S. ranks eighth in worldwide oilseed rape production (http://apps.fas.usda.gov/psdonline/psdQuery.aspx), valued at approximately $\$ 483$ million in $2011 / 2013$, yet the U.S. remains a primary importer of canola oil and meal (http://usda.mannlib.cornell.edu/usda/current/ CropValuSu/CropValuSu-02-14-2014.pdf). Because $80 \%$ of the U.S. canola production is in the state of North Dakota, a public spring canola improvement project was initiated to develop germplasm adaptable to the Northern Plains of the U.S.

High oil yield and quality are fundamental to developing adapted germplasm. The biosynthesis and regulation of oil production in oilseeds is complex encompassing several steps and organelles within the cell (Baud and Lepiniec 2010; Bates et al. 2013; Li-Beisson et al. 2013). Rapeseed or canola oil is a mixture of triacylglycerols (TAG) that account for about 40$45 \%$ of the seed dry weight (Troncoso-Ponce et al. 2011). Initially, compounds like sucrose are imported into the plastid, and through a number of enzymatically mediated steps beginning with a multisubunit heteromeric acetyl-CoA carboxylase (HtACCase), free fatty acids (FA) of 16 to 18 carbons are synthesized. Long-chain FA are then exported to the endoplasmic reticulum (ER) for modification in the form of desaturation and elongation and assembly of TAG, which are esters of glycerol and FA. The formation of very long-chain FA (VLCFA) such as erucic acid (22:1), a major component of non-canola quality rapeseed oil, is enzymatically mediated by the fatty acid elongase complex (FAE), with fatty acid elongation1 (FAE1) being the first of four enzymes that comprise FAE. Synthesis of polyunsaturated FA such as linoleic (18:2) and $\alpha$-linolenic acid (18:3) is mediated by fatty acid desaturase (FAD) enzymes. De novo assembly of TAG occurs by various routes in the ER, with the relatively straight forward one being the Kennedy pathway (Baud and Lepiniec 2010). This pathway encompasses a series of sequential acylation of a glycerol-3-phosphate backbone culminating with the third acylation catalyzed by diacylglycerol acyltransferase (DGAT). Finally, TAGs are stored in oil bodies composed of a matrix of TAGs and various proteins such as oleosins and steroleosin (Baud and Le- 
piniec 2009). The TAGs are important as they act as a reserve for postgermination growth prior to achieving sufficient photosynthetic capacity and comprise the tremendous economic value for oilseed crops such as canola. Thus, it is important to understand the link between various genes involved in the oil biosynthesis during development and composition of seeds as a prelude to germplasm development, as well as to understand factors related to oilseed quality improvement.

While the FA composition in rapeseed oil has been documented (Canvin 1965), employing genomic techniques to evaluate expression of gene transcripts in relation to FA composition during rapeseed development is more recent. Hu et al. (2009) used quantitative reverse transcription (qRT-PCR) to examine transcript levels of 32 genes involved in the biosynthesis of FA, TAG, storage proteins, and in other physiological processes during seed development of an older Chinese high erucic acid cultivar and a descendent, low erucic acid cultivar. They determined that the transcription profiles were similar for both cultivars, while selection pressure for no erucic acid, low glucosinolates, high oleic acid, oil content, and yield affected the expression levels of several genes. In turn, they determined FA levels during seed development and correlated those with the gene transcripts. In another investigation, comparative transcriptome analysis in developing oilseeds of multiple species, including B. napus, relied on expressed sequence tag (EST) database development through pyrosequencing (Troncoso-Ponce et al. 2011). A notable outcome of this study was that regardless of the species ESTs representing almost all reactions of FA biosynthesis had comparable stoichiometry and consistent temporal profiles. This outcome and related results from EST sequencing and gene and protein expression studies suggest it is valid to make some cross species comparisons such as between Arabidopsis thaliana and B. napus (Niu et al. 2009; Venglat et al. 2013).

The first canola-type cultivar of summer rape released in Canada (Stefansson and Kondra 1975) was derived from a complex series of crosses that include selections from Liho and Bronowski to impart low erucic acid and glucosinolates, respectively. Likewise, subsequent canola quality summer rape cultivars, such as Westar and Q2, with superior agronomic and disease resistance traits (Klassen et al. 1987; Stringam et al. 1999) relied on series of crosses using germplasm with low erucic acid and glucosinolates. Westar, released in 1982 by Agriculture and Agri-Food Canada, has been widely cultivated, modified, and used as a baseline for subsequent germplasm development (Juska et al. 1997). However, it is susceptible to a serious disease of canola called blackleg caused by the fungus Leptosphaeria maculans. Q2 released in 1998 by University of Alberta is resistant to blackleg disease and relatively resistant to lodging. We cultivated Bronowski, Westar, and Q2 in the greenhouse to examine for potential traits that could be used in our spring canola breed- 
ing program. Thus, the objectives of this research were to examine fatty acid levels and expression profiles for selected genes associated with the synthesis of FA, TAG, and oil body proteins during seed development in the three cultivars.

\section{MATERIALS AND METHODS}

\section{Plant Materials}

Oilseed rape (Brassica napus) cultivars, Bronowski, Westar, and Q2 were grown in a greenhouse at North Dakota State University, Fargo, ND, USA, at $22 \pm 4^{\circ} \mathrm{C}$ (day and night). The seeds were sown in $15 \mathrm{~cm}$ (diameter) by $15 \mathrm{~cm}$ (depth) pots filled with Sunshine-Mix-1 (Sun Gro Horticulture). The plants were watered daily and fertilized with water soluble $20 \mathrm{~N}-20 \mathrm{P}-20 \mathrm{~K}$ fertilizer. Light in the greenhouse was provided with a 16-h photoperiod by natural sunlight supplemented with $400 \mathrm{~W}$ HPS PL 2000 lights (P.L. Light Systems Inc. ON, Canada). During the flowering stage, plants were bagged (microperforated polybag, Crawford Provincial, ON, Canada) and allowed to self-pollinate. Developing pods were harvested at 5-day intervals, 10 to 40 days after flowering (DAF). Seeds were harvested into liquid nitrogen and stored at $-80^{\circ} \mathrm{C}$ for gas chromatographic analysis and RNA extraction. There were three biological replications per treatment.

\section{Determination of Oil and Fatty Acid Profile}

At $40 \mathrm{~d}$ after flowering (DAF), oil was extracted from seeds with n-hexane using accelerated solvent extraction (Dionex ASE 200, Thermo Scientific, Sunnyvale, CA) according to the methods of Haagenson et al. (2010) for oil content determination. One gram canola seed was oven dried for $4 \mathrm{~h}$ at $70^{\circ} \mathrm{C}$. Seed was milled in a coffee grinder with $3.5 \mathrm{~g}$ diatomaceous earth, and samples were loaded into $11 \mathrm{ml}$ stainless steel cells. Any remaining extraction cell void volume was filled with diatomaceous earth prior to extraction. Extractions were performed at $100^{\circ} \mathrm{C}, 6.7 \mathrm{MPa}$ with a 5 min equilibration time and three $10 \mathrm{~min}$ static cycles having a $100 \%$ flush volume and $60 \mathrm{~s}$ purge time. The solvent containing extracted oil was collected in pre-weighed vials, and solvent was evaporated to dryness with a stream of dry air ($70^{\circ} \mathrm{C}$ dew point). Extracted samples were air dried, and reground for a second extraction and the total oil recovery from the two extractions was recorded. Oil is reported as a percent of seed dry weight.

At $5 \mathrm{~d}$ intervals from 20 to $40 \mathrm{DAF}$, fatty acid profiles were determined on seeds air dried overnight at room temperature in a fume hood. Samples of 0.1 to $0.3 \mathrm{~g}$ of dried seed were ground in a mortar and pestle and vortexed in 0.5 to $2 \mathrm{ml}$ of hexane -chloroform-sodium methoxide (HCSM) derivatization reagent to produce fatty acid methyl esters (FAMEs). The HCSM reagent was freshly prepared by mixing $75 \mathrm{ml}$ hexane, $20 \mathrm{ml}$ chloroform (pentene stabilized), and $5 \mathrm{ml} 0.5 \mathrm{M}$ sodium methoxide in methanol (Sigma \#403067). Analysis of the FAMEs was carried out on 
a Hewlett-Packard 5890 Series II gas chromatograph with a flame-ionization detector. Split injections of $1 \mu 1$ of the FAMEs were separated on a J \& W Scientific DB$23,30 \mathrm{~m}$ by $0.25 \mathrm{~mm}, 0.25 \mu \mathrm{m}$ film column with helium carrier gas at $29 \mathrm{psi}(1.9$ $\mathrm{ml} /$ minute) and split flow at $50-100 \mathrm{ml} /$ minute. The column was temperature programmed at $190^{\circ} \mathrm{C}$ for $4 \mathrm{~min}$ then to $220^{\circ} \mathrm{C}$ at $15^{\circ} \mathrm{C} / \mathrm{min}$ and held $1 \mathrm{~min}$, then to $240^{\circ} \mathrm{C}$ at $25^{\circ} \mathrm{C} / \mathrm{min}$ and held $1 \mathrm{~min}$. Inlet temperature was $230^{\circ} \mathrm{C}$ and detector temperature was $250^{\circ} \mathrm{C}$ with air at $345 \mathrm{ml} /$ minute, hydrogen at $36 \mathrm{ml} /$ minute, and helium makeup gas at $35 \mathrm{ml} /$ minute. Nu-Check $21 \mathrm{~A}$ and 411 standards were used to identify the FAMEs.

\section{Template cDNA preparation and quantitative real-time PCR (qRT-PCR)}

Total RNA was extracted at 5 d intervals from 10 to 40 DAF from canola seeds using the pine tree extraction protocol (Chang et al. 1993), and these samples were used to prepare template cDNA through reverse transcription following manufacturer's instructions (Invitrogen). Briefly, $5 \mu \mathrm{g}$ of total RNA was DNase treated and then reverse transcription was performed in $20 \mu \mathrm{l}$ total volume using a SuperScript First-Strand Synthesis Kit to produce total cDNA from each sample. After cDNA synthesis, each $20 \mu \mathrm{l}$ reaction was diluted to $800 \mu \mathrm{l}$ and stored at $-80^{\circ} \mathrm{C}$.

Gene expression by qRT-PCR was examined using template cDNA on a Roche LightCycler ${ }^{\circledR} 480$ real-time PCR system. Primer pairs were synthesized based on sequences from Hu et al. (2009) (Electronic Supplementary Table S1). qRT-PCR parameters were described previously by Chao (2008) with some modification. The formula used to calculate the fold differences is similar to the comparative $\mathrm{C}_{\mathrm{T}}$ method $\left(\Delta \Delta \mathrm{C}_{\mathrm{T}}\right)$ except that no control sample is incorporated in the calculation. Thus, levels of different target gene expressions can be compared based on the expression of a reference SAND family gene, which served as a base line. A canola SAND family gene was used as a reference because it was verified to be stably expressed during seed development (see Electronic Supplementary Fig. S1 and Table S1 \& S2). The modified formula for fold difference in gene expression of target vs. reference gene is:

$$
\Delta C_{T}=\Delta C_{T \text { target }}-\Delta C_{T \text { reference }}
$$

where, $\Delta \mathrm{C}_{\mathrm{T} \text {,target }}$ is the $\mathrm{C}_{\mathrm{T}}$ value of the target gene, and $\Delta \mathrm{C}_{\mathrm{T} \text {,reference }}$ is the $\mathrm{C}_{\mathrm{T}}$ value of the reference gene. SYBR green chemistry was used to produce fluorescent signal, and three technical replicates were used per sample for the RTqPCR experiments. The $\mathrm{C}_{\mathrm{T}}$ value of each gene is the average of three technical replicates. The difference in gene expression is designated as $\log 2$ value. Heatmap of the qRT-PCR results in Fig. S1 was created based on $\log 2$ values using Eisen Lab software, Cluster and TreeView as described by Eisen et al. (1998). 


\section{Statistical Analysis}

The standard error (SE) of the mean difference of $\mathrm{Ct}$ values between the target and reference (SAND family) genes were calculated based on

$$
S_{\bar{Y}_{A}-\bar{Y}_{B}}=\sqrt{\frac{S_{A}^{2}}{n_{A}}+\frac{S_{B}^{2}}{n_{B}}-2 \cdot \widehat{\rho}_{A, B} \cdot \frac{S_{A}}{\sqrt{n_{A}}} \cdot \frac{S_{B}}{\sqrt{n_{B}}}}
$$

where $S_{A}$ and $S_{B}$ are the standard deviations and $n_{A}$ and $n_{B}$ are the sample sizes for samples $A$ and $B . \widehat{P}_{A B}$ is the estimated correlation of these pairs. The $95 \%$ confidence intervals were obtained based on the mean difference $\pm t$ -value $\times S E$; the $t$-value with 2 degrees of freedom and $95 \%$ confidence is 4.303. The variance sum law was applied in the calculation of each reference gene normalized target gene SE and explains why the 95\% confidence intervals for most of the target genes appeared very large.

MANOVA was used to compare FA profiles among cultivars using the manova function of the stats package in R (2015). The Wilks Lambda statistic was used to determine significant difference for the FA profiles (Johnson and Wichern 2007).

Pearson correlation coefficients between the FA and the gene expression by cultivar were computed using the cor function of the stats package in $\mathrm{R}$ (2015). Because only three biological replications were used in this study for each cultivar and DAF, only large effects and/or strong associations could be expected to be detected statistically.

RESULTS

\section{Oil and Fatty Acids}

The seed oil content of Bronowski, Westar, and Q2 grown in the greenhouse was 39.0, 40.6, and $40.1 \%$, respectively. During the 20 to $40 \mathrm{~d}$ period of seed development, cultivars had varying levels of palmitic, stearic, oleic, linoleic, $\alpha$-linolenic, eicosenioc acid, and erucic acid (Fig. 1). Levels of the two saturated FA, palmitic acid and stearic acid, were similar among the cultivars averaging $7.5 \%$ and $4.4 \%$ and $2.5 \%$ and $1.9 \%$, respective at 20 and 40 DAF. The level of oleic acid was the same in Westar and Q2 over the 20 to $40 \mathrm{~d}$ period, although there was a trend for slightly high levels in Westar. In contrast, the mean level of oleic acid in Bronowski seeds was about $25 \%$ lower over the $20 \mathrm{~d}$ period relative to Westar and Q2. In general, the levels for two polyunsaturated FA, linoleic acid and $\alpha$-linolenic acid, were similar among the cultivars averaging $22.2 \%$ and $15.7 \%$ and $10.8 \%$ and $6.1 \%$, respective at 20 and $40 \mathrm{DAF}$. Nevertheless, the trend was for higher levels of linoleic acid in Q2 > Westar > Bronowski seeds from 20 to 40 DAF. The monounsaturated VLCFAs, eicosenioc acid and erucic acid, varied tremendously among the cultivars, particularly for Bronowski. Eicosenioc acid 
levels over the 20 to $40 \mathrm{~d}$ period averaged $16.3 \%, 1.5 \%$ and $1.4 \%$, respective for Bronowski, Westar, and Q2 seeds. Erucic acid was not detected in Westar seeds and the levels in Q2 were $3 \%$ and $1.1 \%$ at 35 and 40 DAF, respectively. In contrast, erucic acid levels in Bronowski seeds increased from $10.9 \%$ to $22.5 \%$ of total FAs over the 20 to $40 \mathrm{~d}$ period.



Fig. 1. Fatty acid accumulation during seed development.

The levels of 7 fatty acids (palmitic, stearic, oleic, linoleic, $\alpha$-linolenic, eicosenioc, and erucic acid) were examined at 5-day intervals, 20 to 40 DAF in cultivars Bronowski, Westar, and Q2

\section{Gene Expression}

Gene designation, role, and location are provided in Table 1. Overall and as determined by the $95 \%$ confidence intervals, gene expression among the three cultivars was similar from 10 to 35 DAF (Fig. 2). We had only one data point for Bronowski genes at $40 \mathrm{DAF}$ so confidence intervals could not be calculated. The few exceptions were that expression of KASI and $S A D$ were higher in Westar and Q2 than in Bronowski at $25 \mathrm{DAF}, S A D$ was highest in Q2, intermediate in Westar, and lowest in Bronowski at $35 \mathrm{DAF}$, FAD2 expression was higher in Q2 than in Bronowski at $35 \mathrm{DAF}$, FAD3 expression was higher in Q2 than in Bronowski at $15 \mathrm{DAF}$ and Q2 and Westar at 25 and $30 \mathrm{DAF}$, and FAE1 expression was higher in Westar and Q2 than in Bronowski at 30 DAF. At its peak, expression of the gene for the seed storage protein napin was nearly 33,000 fold higher ( $\log _{2}$ of 15$)$ than the SAND gene. Conversely, lowest level of expression was the caleosin gene at 1/64 $\left(\log _{2}\right.$ of -6$)$ that of the SAND gene at $10 \mathrm{DAF}$. 
Gene designation, role, and location

\begin{tabular}{|c|c|c|c|}
\hline Gene name & Gene annotation & Role & Location \\
\hline ACCase & Homeomeric acetyl CoA carboxylase & Fatty acid biosynthesis & Cytosol \\
\hline$\alpha-C 7$ & Alpha carboxyltransferase & Fatty acid biosynthesis & Plastid \\
\hline$\beta-C 7$ & Beta carboxyltransferase & Fatty acid biosynthesis & Plastid \\
\hline$B C$ & Biotin carboxylase & Fatty acid biosynthesis & Plastid \\
\hline$M C M T$ & Malonyl-CoA:ACP malonyltransferase & Fatty acid biosynthesis & Plastid \\
\hline KAS1 & Beta-ketoacyl-ACP synthase 1 & Fatty acid biosynthesis & Plastid \\
\hline KAS2 & Beta-ketoacyl-ACP synthase 2 & Fatty acid biosynthesis & Plastid \\
\hline KAS3 & Beta-ketoacyl-ACP synthase 3 & Fatty acid biosynthesis & Plastid \\
\hline$H D / K A C D$ & 3-hydroxyacyl-ACP dehydratase & Fatty acid biosynthesis & Plastid \\
\hline$S A D$ & Stearoyl-ACP desaturase & Fatty acid biosynthesis & Plastid \\
\hline FatA & Acyl-ACP thioesterasae & Fatty acid biosynthesis & Plastid \\
\hline FatB & Palmiottoyl-ACP thioesterase & Fatty acid biosynthesis & Plastid \\
\hline FAD6 & Oleate desaturase & Acid editing & Plastid \\
\hline$F A D 2$ & Oleate desaturase & Acid editing & Endoplasmatic reticulum \\
\hline$F A D 3$ & Linoleate desaturase & Acid editing & Endoplasmatic reticulum \\
\hline LPATT & Lysophosphatidic acid acyltransferase & Triacylglycerol biosynthesis & Endoplasmatic reticulum \\
\hline$D G A T 2$ & Acyl-CoA:diacylglycerol acyltransferase & Triacylglycerol biosynthesis & Endoplasmatic reticulum \\
\hline AAPT1 & Aminoalcoholphosphotransferase & Triacylglycerol biosynthesis & Endoplasmatic reticulum \\
\hline FAE1 & Fatty acid elongase 1/3-ketoacyl-CoA synthase & $\begin{array}{l}\text { Very long chain fatty acid } \\
\text { biosynthesis }\end{array}$ & Endoplasmatic reticulum \\
\hline KCR2 & 3-ketoacyl-CoA reductase & $\begin{array}{l}\text { Very long chain fatty acid } \\
\text { biosynthesis }\end{array}$ & Endoplasmatic reticulum \\
\hline Oleosin & Oil nody associated protein & Storage protein & Oil body \\
\hline Cruciferin & 12S neutral oil body protein & Storage protein & Oil body \\
\hline Napir & $1.7 \mathrm{~S}$ oil body protein & Storage protein & Oil body \\
\hline Caleosin & $\mathrm{Ca}^{2+}$ binding oil body surface protein & Storage protein & Oil body \\
\hline
\end{tabular}




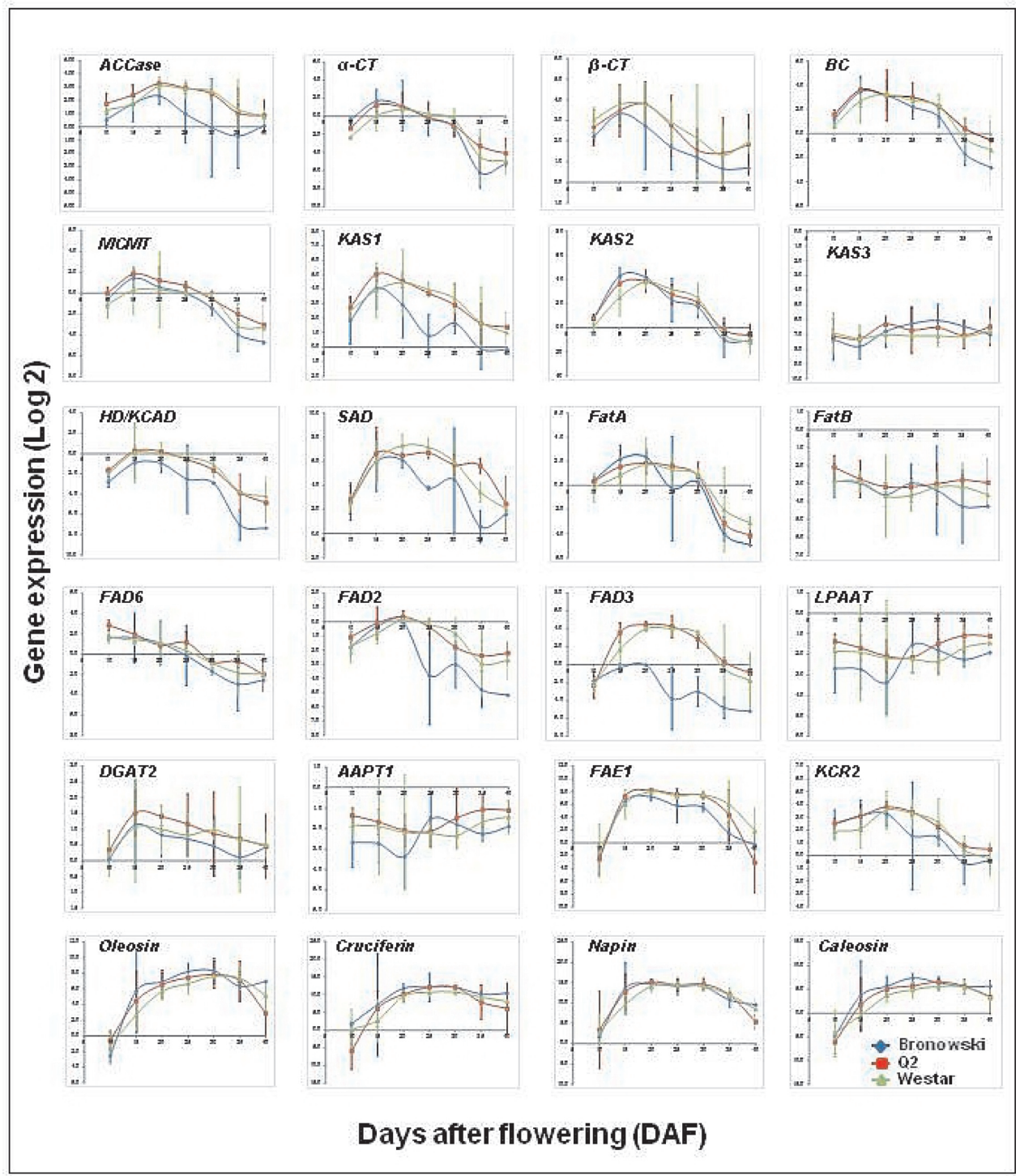

Fig. 2. Gene expression profiles during seed development.

The expression profiles of 24 genes were examined at 5-day intervals, 10 to 40 DAF in cultivars Bronowski, Westar, and Q2. Levels of different target gene expressions were compared based on the expression of a reference SAND family gene, which also served as a base line here. The fold difference is designated as $\log 2$ value. Gene designation is in Table 1 . The $95 \%$ confidence intervals were obtained based on the mean difference $\pm t$-value $\times \mathrm{SE}$ 
$\frac{\sqrt{4}}{\frac{9}{4}}$

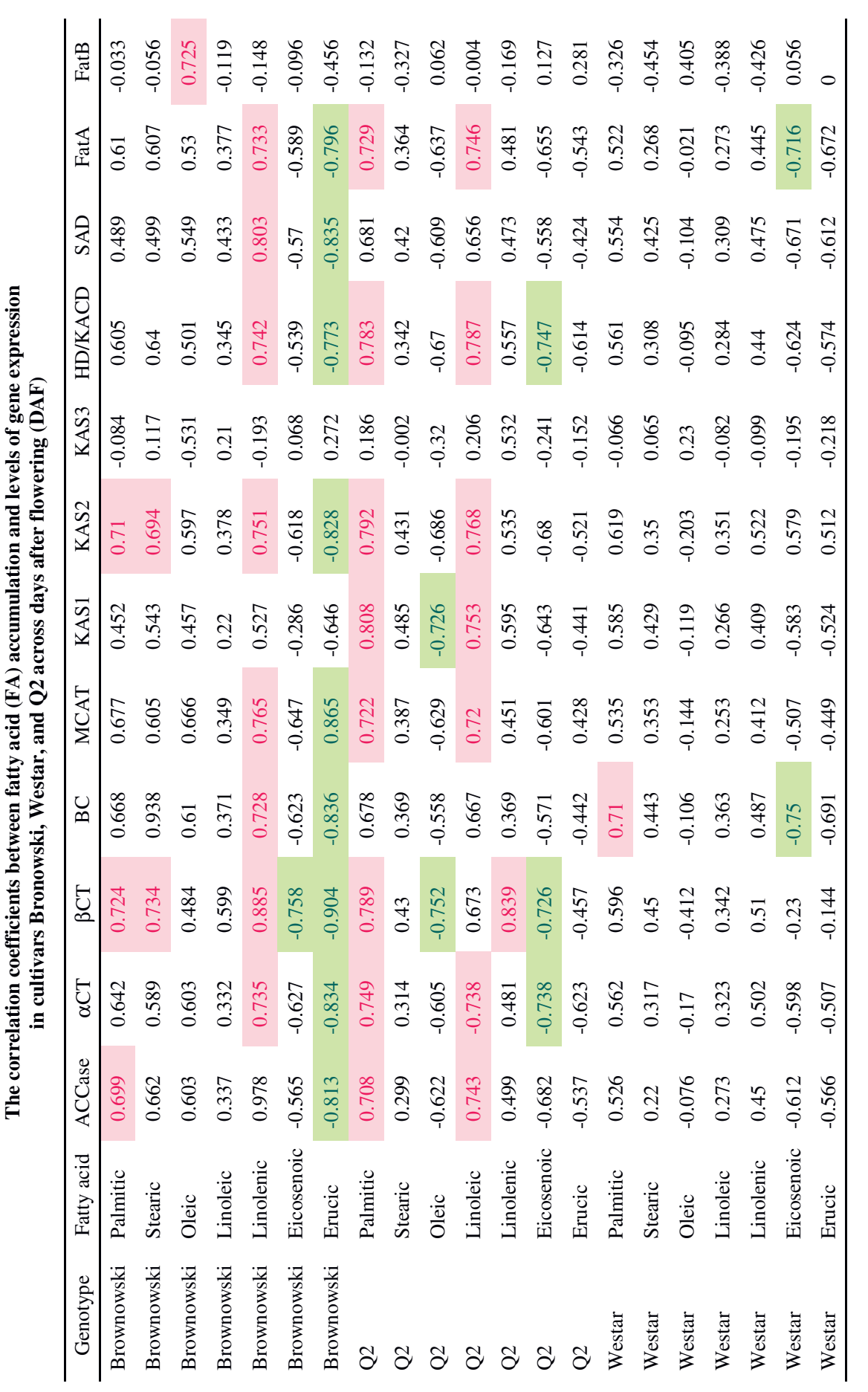









\section{Correlations}

We examined the correlation between FA levels and gene expression across DAF for each cultivar. The data support a common trend in gene expression among the three cultivars with gene expression tending to decrease over time; except for $L P A A T$, which tended to increase (Electronic Supplementary Table $\underline{\mathrm{S} 3}$ ). In our subsequent determination of the correlation between the level of FAs and expression of genes by individual cultivar, we observed no consistent relationship between FA and gene expression, rather these correlations seem to depend on the individual cultivar (Table 2). Forty-eight (red) and 27 (green) coefficients displayed significant $(\mathrm{P}<0.05)$ positive and negative correlations, respectively. Of these, 43, 29, and 3 were associated with Bronowski, Q2, and Westar, respectively. The correlation coefficients ranged from a positive correlation of 0.88 for $\beta$ - $C T$ and $\alpha$-linolenic acid in Bronowski, to no correlation between $F a t B$ and erucic acid in Westar, to a highly negative correlation of -0.95 between FAD6 and erucic acid in Bronowski. Interestingly, for Bronowski and $\mathrm{Q} 2,52 \%\left(\mathrm{r}^{2}=0.72\right)$ or more of the variation in the expression of $\beta$-CT was related to variation in the level of palmitic acid, $\alpha$-linolenic acid, and eicosenioc acid. In this case for Bronowski and Q2, expression of $\beta$-CT was positively correlated with levels of palmitic acid and $\alpha$-linolenic acid, whereas levels of eicosenioc acid were negatively correlated with $\beta-C T$. For oleic acid, the correlations coefficients for most genes were positive for Bronowski but negative for Q2 and Westar; although most of the correlation coefficients were not significantly different. There were no significant correlations between the level of any fatty acid for the three cultivars and expression of KAS3, Oleosin, and Caleosin genes when correlations were computed across DAF.

\section{DISCUSSION}

We designed this investigation of $B$. napus seed development after a similar study by Hu et al. (2009). They examined an older high erucic acid cultivar Zhongyou 821 (ZY821) and a low erucic acid descendant of ZY821, Zhongshuang 9 (ZS9). In turn, we employed several cultivars important for breeding improved germplasm adapted to a region of the U.S. where $80 \%$ of the spring canola is produced. The level of seed oil at maturity in our three greenhouse grown cultivars was 2.7 to $7.7 \%$ lower than the content reported for seeds of these cultivars from field grown plants (Bronowski 41.7\%, Westar 43.3\%, and Q2 47.8\%), but were similar to the level in rapeseed cultivars (ZY821 39.8\%, ZS9 $42 \%$, respectively).

The abundance of FA in our three cultivars was typical relative to another report with oleic acid $>$ linoleic $>\alpha$-linolenic (Vuorinen et al. 2014). The VLCFAs, eicosenioc acid and erucic acid, as reported previously Finlayson et al., 1973, were higher in Bronowski at the expense of oleic acid, which is the 
economically important FA component. In contrast to the level of eicosenioc acid in Bronowski (17\%), the level in ZY821 was reduced by about one-half $(9.75 \%)$; whereas, the level of erucic acid in Bronowski (21\%) was reduced by about one-half the level in ZY821 (42\%) (Hu et al. 2009). These difference likely reflect dissimilarity in genetic background of the cultivars.

We examined nearly the same set of genes as reported by Hu et al. (2009), but direct comparison is problematic because different reference genes $(\beta$-actin vs. $S A N D$ ) were utilized for qRT-PCR normalization, different statistical procedures were employed, and we expressed our data on a $\log 2$ scale. To compare fold differences between relative copy number data (Hu et al. 2009) and our $\log 2$ scale data would require numerical data for the qRT-PCR done by $\mathrm{Hu}$ et al. (2009). This is because fold estimates are not possible when the relative copy number value is close to zero as is the case for many of the genes they examined. Nevertheless, similarities and differences in general trends can be discerned (see Fig. 2 (Hu et al. 2009)). For example, the biosynthesis of FAs begins with ACCase catalyzing the carboxylation of acetyl-CoA to malonyl-CoA. Expression of $\beta$-CT, a gene encoding for $\beta$-carboxyltransferase, one of four components of the heteromeric ACCase, is nearly the same in the two studies, increasing by about 2 fold from 10 to $15 \mathrm{DAF}$ and thereafter decreasing about 2 fold by 35 DAF. Expression of FAE1, a component of a multienzyme complex involved in VLCFA biosynthesis, increases by 5 fold from 25 to 40 DAF in ZY821 and thereafter decreased to the 25 DAF level; whereas, the expression peaks $(\log 2=7)$ around 15 DAF in Bronowski and thereafter decreases 128 fold by $40 \mathrm{DAF}(\log 2=0)$.

The expression profile of the seed storage proteins was similar among Westar, Q2, and Bronowski, which was similar to that observed based on a comparison between Westar and Reston (Katavic et al. 2002), another high erucic acid (26\%) low oleic acid (30\%) cultivar similar to Bronowski. However, the expression profiles of the seed storage proteins between our cultivars and ZY821 and ZS9 differed (see Fig. 2 (Hu et al. 2009)). For example, oleosin, which is the major protein component of oil bodies, narrowly peaked at $40 \mathrm{DAF}$ in ZY821 with a relative copy number of $25,000(\log 2=14.6)$ and 12,500 for ZS9 $(\log 2=13.6)$; whereas in the cultivars we examined the broad peak occurred around $25 \mathrm{DAF}$ with a $\log 2=7$. However, the napin gene, which accounted for over $75 \%$ of total transcription from all 32 genes assessed by $\mathrm{Hu}$ et al. (2009), and displayed the highest level of expression among the genes we assessed, had nearly the same level of expression at its peak; ZY821 and ZS9 peaked at 40 and $35 \mathrm{DAF}$, respectively with a similar relative copy number of $175,000(\log 2=17.4)$; whereas in the cultivars we examined the broad peak occurred around $25 \mathrm{DAF}$ with a $\log 2=13$. In any event, the seed storage protein genes in both studies generally displayed the highest level of expression of the genes assessed. 
Some of the genes we appraised were significantly correlated with fatty acid accumulation, especially for the Bronowski and Q2 cultivars. In particular, the level of several FAs was correlated with $\beta$-CT expression. $\beta$ - $C T$ encodes for one of the subunits $(\alpha-\mathrm{CT}, \beta-\mathrm{CT}$ and $\mathrm{BC})$ for the plastid localized heteromeric ACCase, which catalyzes the first committed step of fatty acid biosynthesis. This gene is thought to be unique in that it is the only known lipid metabolism gene that is encoded by the plastid genome (Elborough et al. 1996; Li-Beisson et al. 2013). In the high erucic acid cultivars Bronowski and ZY821, $\beta$-CT expression was negatively correlated with erucic acid, whereas $\beta$-CT expression was positively correlated with palmitic acid, steric acid, $\alpha$-linoleic acid in Bronowski, but not in ZY821 (Hu et al. 2009). Perhaps there is a negative correlation between erucic acid levels and $\beta$-CT expression because expression of this gene is declining, while erucic acid levels increase after 25 DAF.

Different patterns of gene expression exists for FAE1 between the high erucic acid cultivars Bronowski and ZY821 (Hu et al. 2009). FAE1 is a component of the multi-enzyme complex involved in VLCFA biosynthesis; mutations in the FAE1 gene are responsible for the low erucic acid trait (Puyaubert et al. 2005). Erucic acid levels peak by 30 DAF in Bronowski, whereas the levels substantially increases in ZY821 until 40 DAF. Thus, the negative correlation coefficient (-0.78) that we observed for FAE1 and erucic acid in Bronowski is consistent with a large fold decrease in gene expression and slightly increased level of erucic acid as Bronowski seeds mature. However, the positive correlation (0.78) between erucic acid and FAE1 for ZY821 is likely explained by the much different temporal pattern of $F A E 1$ expression and erucic acid accumulation (see Fig. 2 (Hu et al. 2009)). The high level of FAEl expression in low erucic acid cultivars such as Q2, ZS9 and other cultivars (Hu et al. 2009; Vuorinen et al. 2014) might seem inconsistent with the absence of VLCFAs. However, as mentioned, FAEl gene contains a mutation that result in the absence of 3-ketoaacylCoA synthase protein, thus preventing the synthesis of VLCFAs (Puyaubert et al. 2005; Wu et al. 2008). Interestingly, Westar contains a point mutation while ZS9 contains a point mutation and four base pair deletion (Katavic et al. 2006; Wu et al. 2008). Overall, appraisal of the correlation coefficients, which are sometimes different between our cultivars and the Chinese cultivars investigated by Hu et al. (2009), is instructive of the different patterns of gene expression in relation to a particular FA or storage protein.

The results of this investigation, which employed three publically available cultivars from Canadian breeding programs, provide background data into the transcriptional network for FA, TAG, and seed storage proteins. By comparing the outcome of our investigation to that of Hu et al. (2009), we further demonstrated that genetic background of the cultivars from different breeding programs affects important metabolic and molecular responses during oilseed development. In any event, these insights and benchmark data will be important 
for the success of the recent public spring canola improvement project we initiated to develop germplasm adaptable to the Northern Plains of the U.S.

\section{ACKNOWLEDGEMENTS}

Research funded by the America for Bulgaria Foundation through the USDAForeign Agricultural Service, which provided financial and administrative support for Dr. Mariana Petkova and the USDA-Agricultural Research Service project \#3060-21220-026. Dr. Darrin Haagenson conducted the oil analysis, and Cheryl Huckle, Wayne Sargent, Angela Adsero, and Andrew Ross provided technical support.

\section{REFERENCES}

Bates PD, Stymne S, Ohlrogge J (2013) Biochemical pathways in seed oil synthesis. Curr. Opin. Plant Biol. $16,358-364$.

Baud S, Lepiniec L (2009) Regulation of de novo fatty acid synthesis in maturing oilseeds of Arabidopsis. Plant Physiol. Biochem. 47, 448-455.

Baud S, Lepiniec L (2010) Physiological and developmental regulation of seed oil production. Prog. Lipid Res. 49, 235-249.

Canvin DT (1965) The effect of temperature on the oil content and fatty acid composition of the oils from several oil seed crops. Can. J. Bot. 43, 63-69.

Chang S, Puryear J, Cairney J (1993) A simple and efficient method for isolating RNA from pine trees. Plant Mol. Biol. Rep. 11, 113-116.

Chao WS (2008) Real-time PCR as a tool to study weed biology. Weed Sci. 56, 20-296.

Eisen MB, Spellman PT, Brown PO, Botstein D (1998) Cluster analysis and display of genome-wide expression patterns. Proc. Natl. Acad. Sci. USA 95, 14863-14868.

Elborough KM, Winz R, Deka RK, Markham JE, White AJ, Rawsthorne S, Slabas AR (1996) Biotin carboxyl carrier protein and carboxyltransferase subunit form of acetyl-CoA carboxylase from Brassica napus: cloning and analysis of expression during oilseed rape embryogenesis. Biochem. J. 315, 103-112.

Finlayson AJ, Krzymanski J, Downey RK (1973) Comparison of chemical and agronomic characteristics of two Brassica napus L. cultivars, Bronowski and Target. J. Am. Chem. Soc. 50, 407-410.

Haagenson DM, Brudvik RL, Lin H, Wiesenborn DP (2010) Implementing an in situ alkaline transesterification method for canola biodiesel quality screening. J. Am. Oil Chem. Soc. 87, 1351-1358.

$\mathrm{Hu}$ Y, Wu G, Cao Y, Wu Y, Xiao L, Li X, Lu C (2009) Breeding response of transcript profiling in developing seeds of Brassica napus. BMC Mol. Biol. 10, 49.

Johnson RA, Wichern DW (2007) Applied Multivariate Statistical Analysis, Pearson Prentice-Hall, Upper Saddle River, NJ.

Juska A, Busch L, Wu FH (1997) Producing genetic diversity in crop plants: the case of Canadian rapeseed, 1954-1991. J. Sustain. Agric. 9, 5-23.

Katavic V, Agrawal GK, Hajduch M, Harris SL, Thelen JJ (2006) Protein and lipid composition analysis of oil bodies from two Brassica napus cultivars. Proteomics 6, 4586-4598.

Katavic V, Mietkiewska E, Barton DL, Giblin EM, Reed DW, Taylor DC (2002) Restoring enzyme activity in nonfunctional low erucic acid Brassica napus fatty acid elongase 1 by a single amino acid substitution. Eur. J. Biochem. 269, 5625-5631.

Klassen AJ, Downey RK, Capcara JJ (1987) Westar summer rape, Can. J. Plant Sci. 67, 491-493.

Li-Beisson Y, Shorrosh B, Beisson F, Andersson MX, Arondel V, Bates PD, Baud S, Bird D, DeBono A, Durrett TP, Franke RB, Graham IA, Katayama K, Kelly AA, Larson T, Markham JE, Miquel M, Molina I, Nishida I, Rowland O, Samuels L, Schmid KM, Wada H, Welti R, Xu C, Zallot R, Ohlrogge J (2013) Acyl-lipid metabolism. In The Arabidopsis Book, The Am. Soc. Plant Biol., Rockville, MD, p. e0133.

Niu Y, Wu GZ, Ye R, Lin WH, Shi QM, Xue LJ, Xu XD, Li Y, Du YG, Xue HW (2009) Global analysis of gene expression profiles in Brassica napus developing seeds reveals a conserved lipid metabolism regulation with Arabidopsis thaliana. Mol. Plant 2, 1107-1122. 
Puyaubert J, Garcia C, Chevalier S, Lessire R (2005) Acyl-CoA elongase, a key enzyme in the development of high-erucic acid rapeseed? Eur. J. Lipid Sci. Technol. 107, 263-267.

R Core Team, http://www.r-project.org/, last accessed 15 November 2015.

Stefansson BR, Hougen FW, Downey RK (1961) Note on the isolation of rape plants with seed oil free from erucic acid. Can. J. Plant Sci. 41, 218-219.

Stefansson BR, Kondra ZP (1970) Inheritance of the major glucosinolates of rapeseed (Brassica napus) meal. Can. J. Plant Sci. 50, 643-648.

Stefansson BR, Kondra ZP (1975) Tower summer rape. Can. J. Plant Sci. 55, 343-344.

Stringam GR, Degenhardt DF, Thiagarajah MR, Bansal VK (1999) Q2 summer rape. Can. J. Plant Sci. 79, 597-598.

Troncoso-Ponce MA, Kilaru A, Cao X, Durrett TP, Fan J, Jensen JK, Thrower NA, Pauly M, Wilkerson C, Ohlrogge JB (2011) Comparative deep transcriptional profiling of four developing oilseeds. Plant J. 68, 1014-1027.

Venglat P, Xiang D, Yang H, Wan L, Tibiche C, Ross A, Wang E, Selvaraj G, Datla R (2013) Gene expression profiles during embryo development in Brassica napus. Plant Breed. 132, 514-522.

Vuorinen AL, Kalpio M, Linderborg KM, Kortesniemi M, Lehto K, Niemi J, Yang B, Kallio HP (2014) Coordinate changes in gene expression and triacylglycerol composition in the developing seeds of oilseed rape (Brassica napus) and turnip rape (Brassica rapa). Food Chem. 145, 664-673.

Wu G, Wu Y, Xiao L, Li X, Lu C (2008) Zero erucic acid trait of rapeseed (Brassica napus L.) results from a deletion of four base pairs in the fatty acid elongase 1 gene. Theor. Appl. Genet. 116, 491-499. 


\section{SUPLEMENTARY FIGURE AND TABLES}

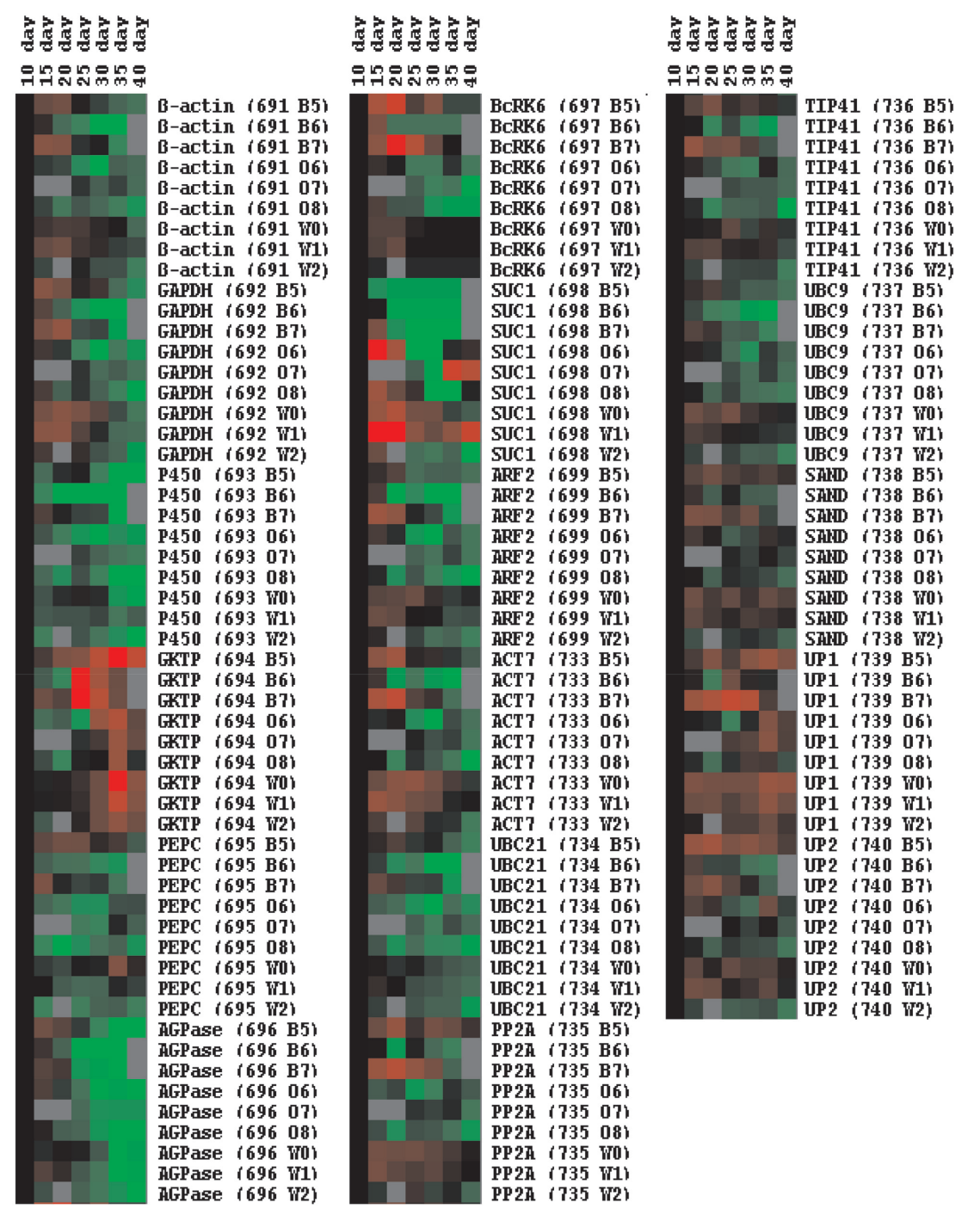

Heat map of various genes including SAND family gene. The formula used to calculate the fold differences is similar to the standard comparative $C_{T}$ method $\left(\Delta \Delta C_{T}\right)$ except that no endogenous reference gene is incorporated in the calculation since we want to determine stably expressed genes before normalization. The modified formula for fold difference in gene expression of test vs control sample is $\Delta \mathrm{C}_{\mathrm{T}}=\Delta \mathrm{C}_{\mathrm{T} \text {,est }}$ $\Delta \mathrm{C}_{\mathrm{T} \text {,control. }}$. Here, $\Delta \mathrm{C}_{\mathrm{T} \text {,test }}$ is the $\mathrm{C}_{\mathrm{T}}$ value of the test sample, and $\Delta \mathrm{C}_{\mathrm{T}, \text { control }}$ is the $\mathrm{C}_{\mathrm{T}}$ value of the control sample, a 10 day sample (see Supplementary Table S1 for gene designation and primer sequences).

Suplementary Fig S1 


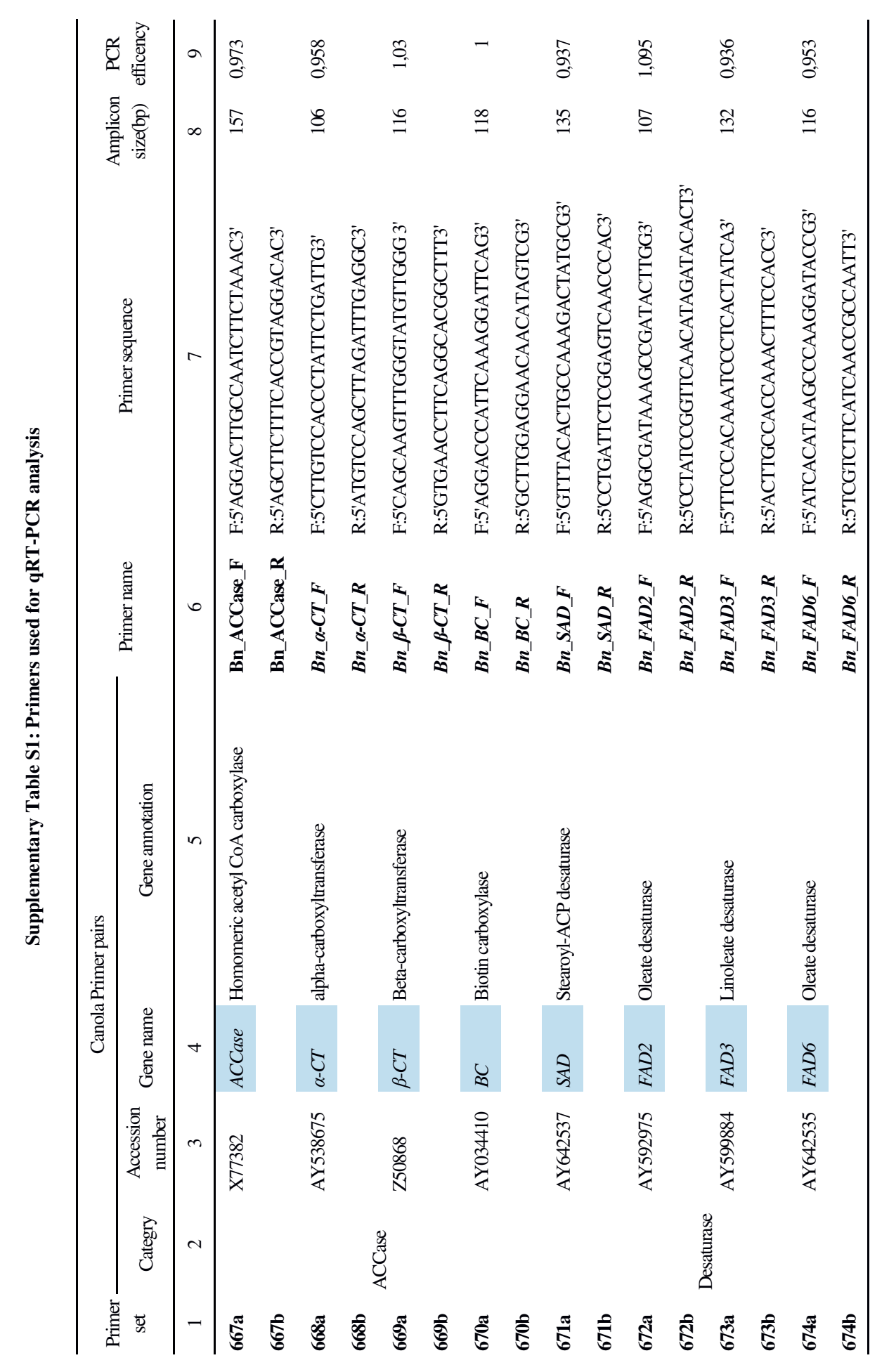




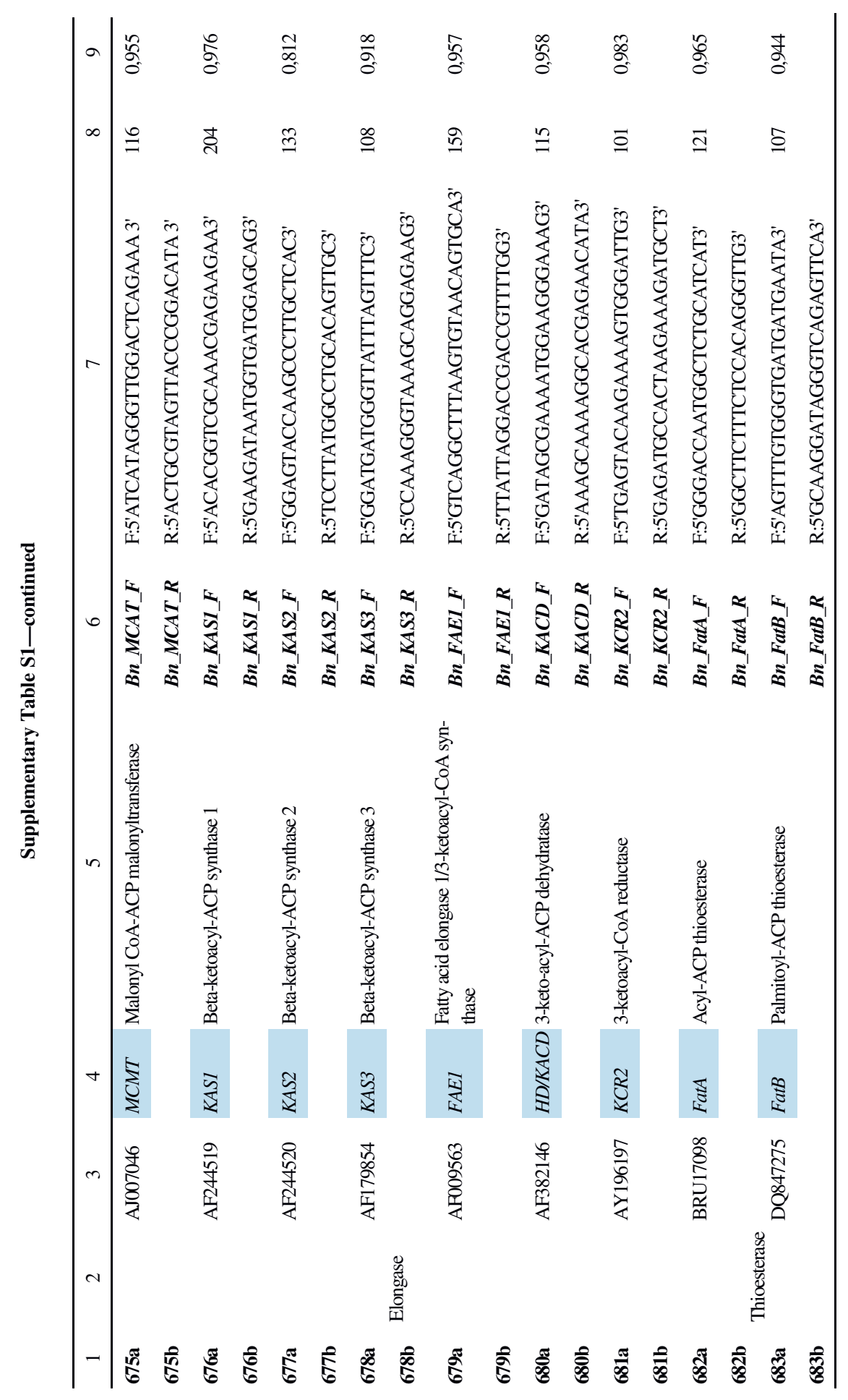




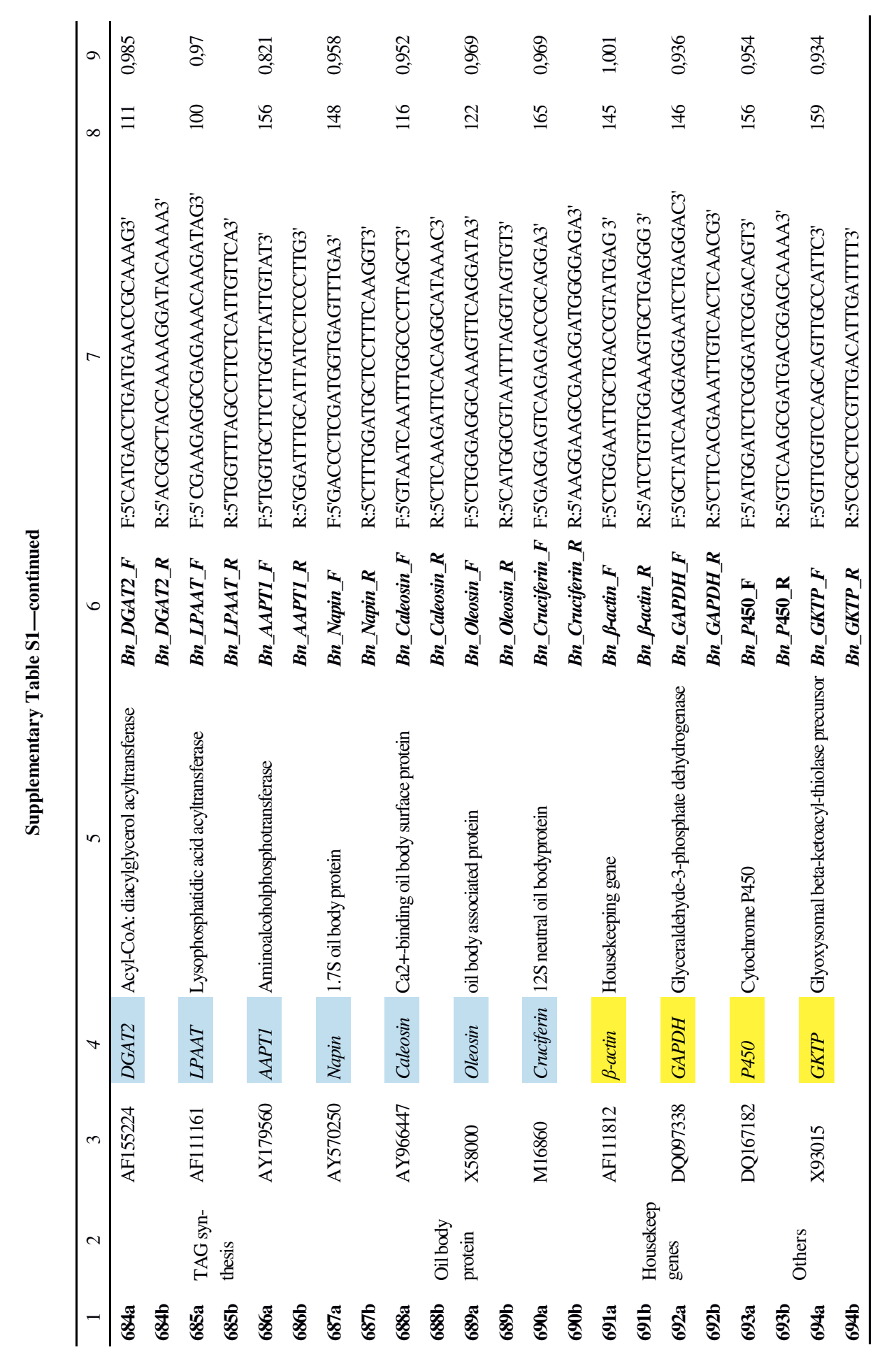









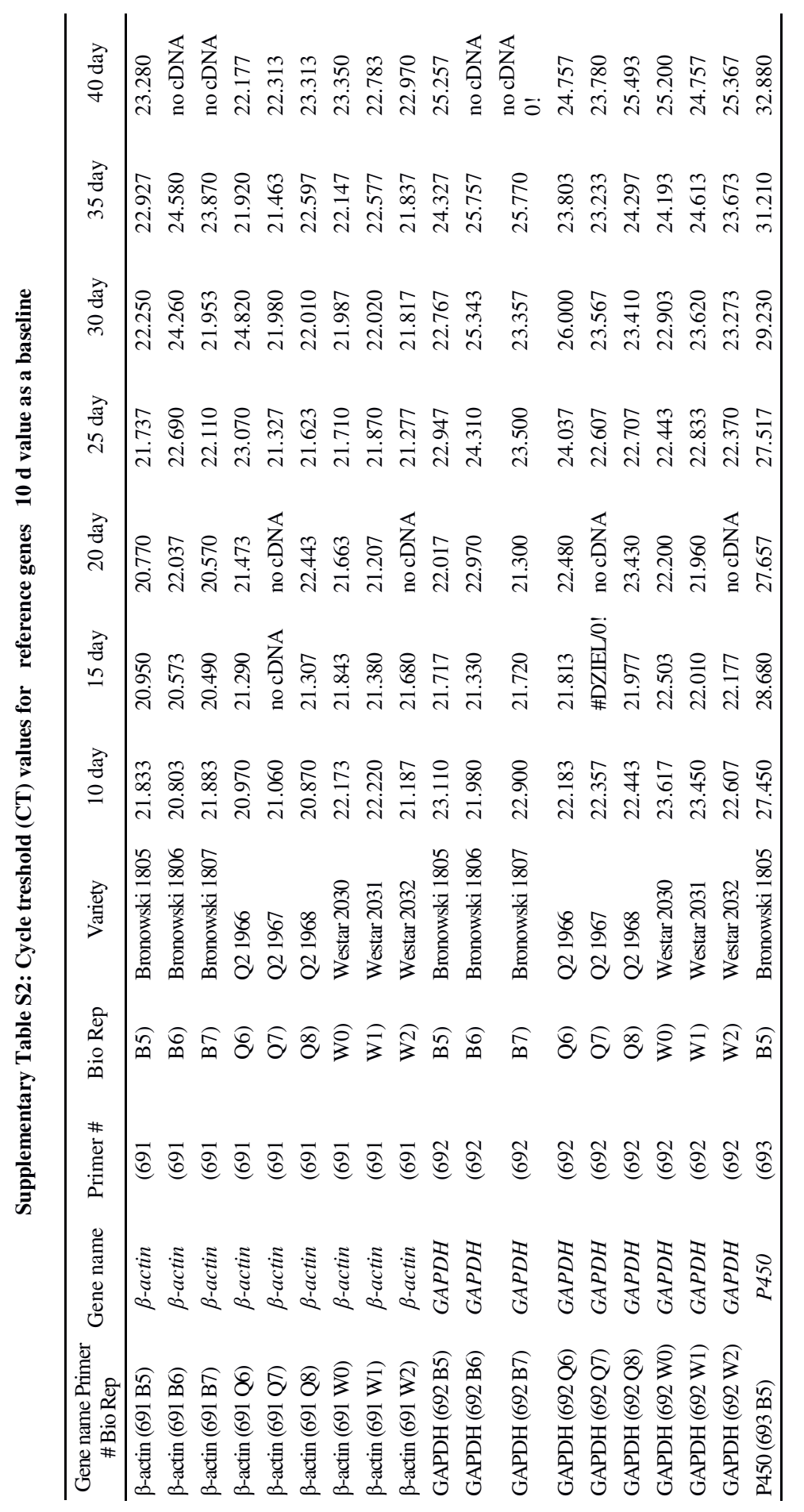









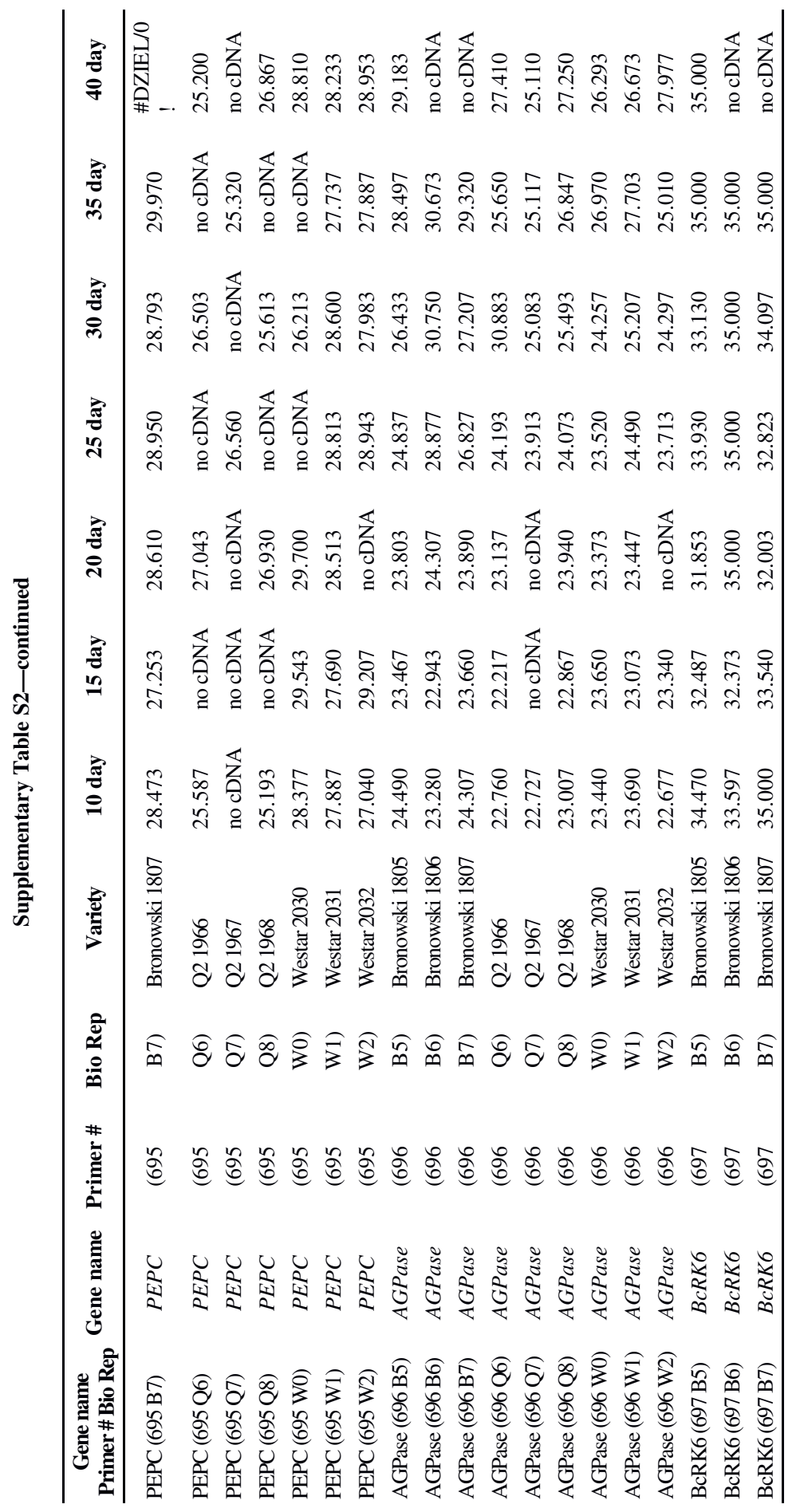




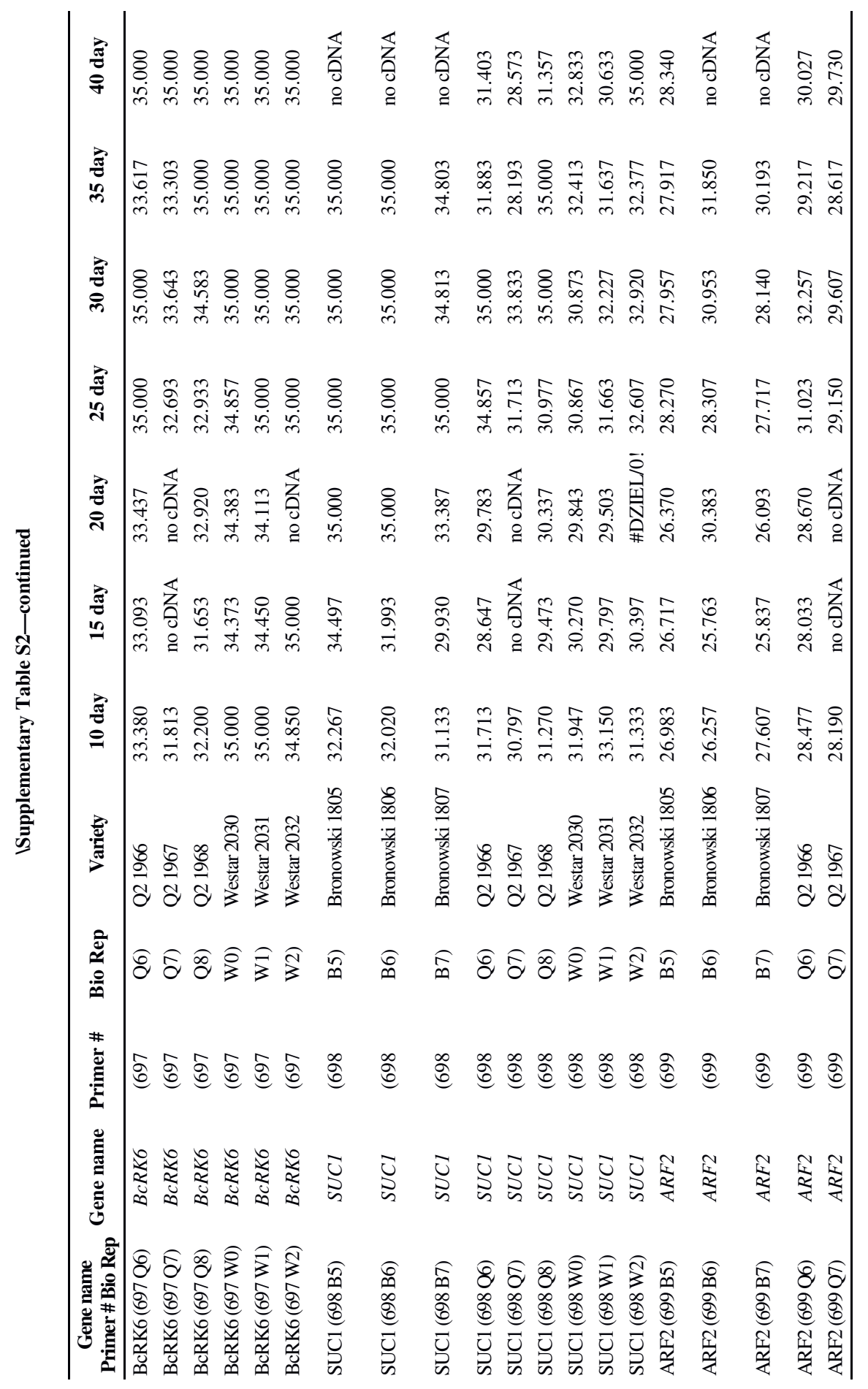




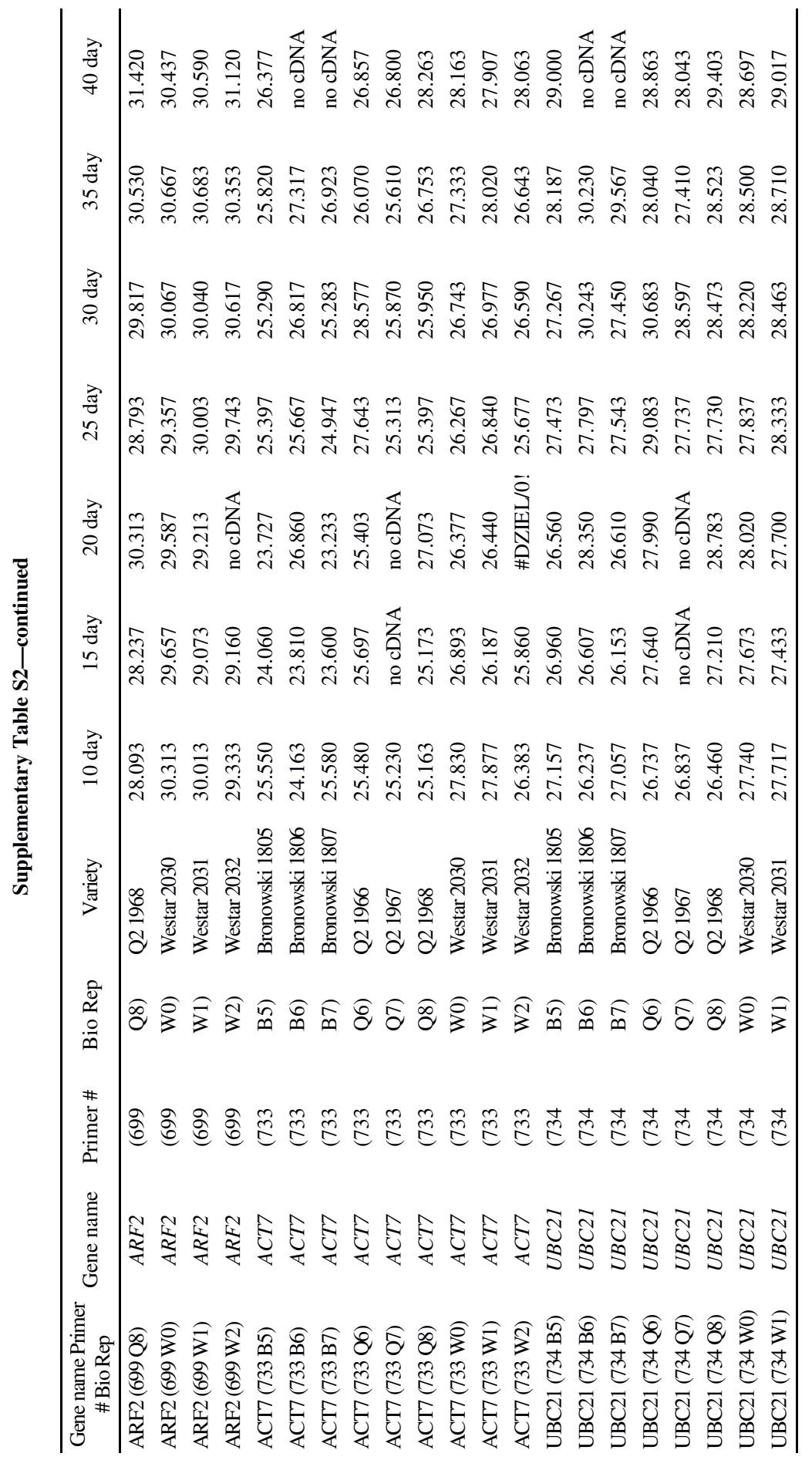




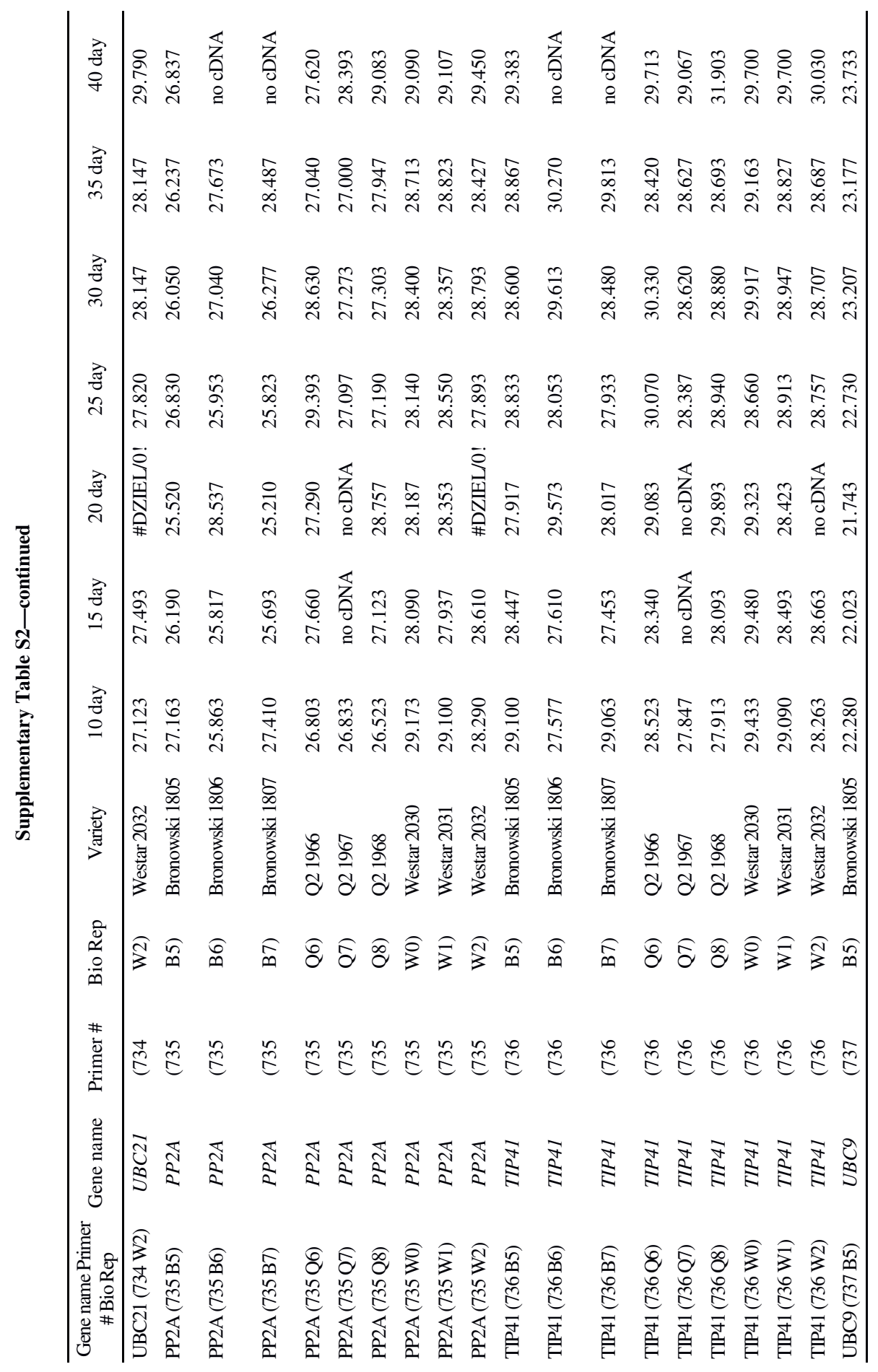




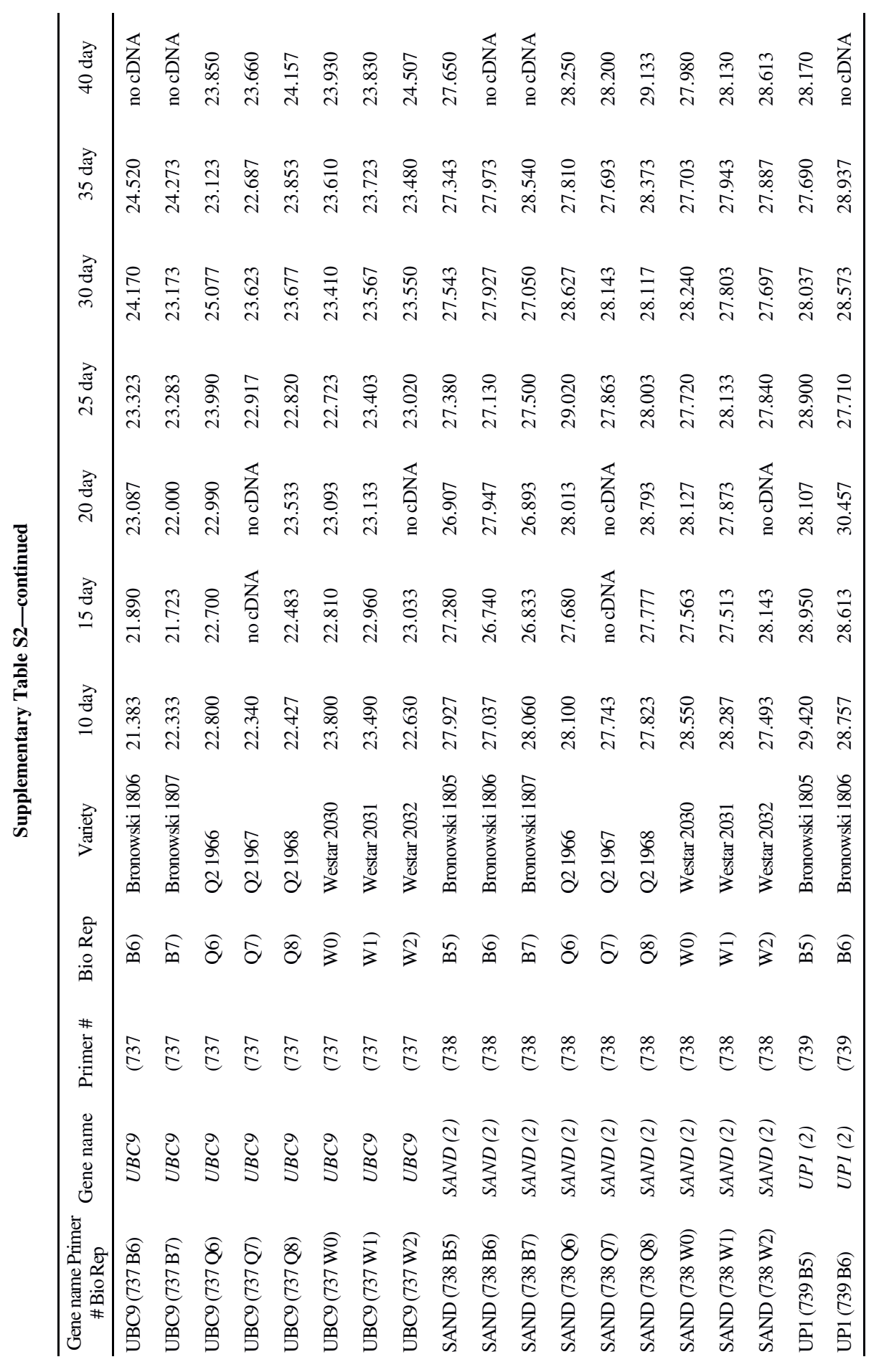




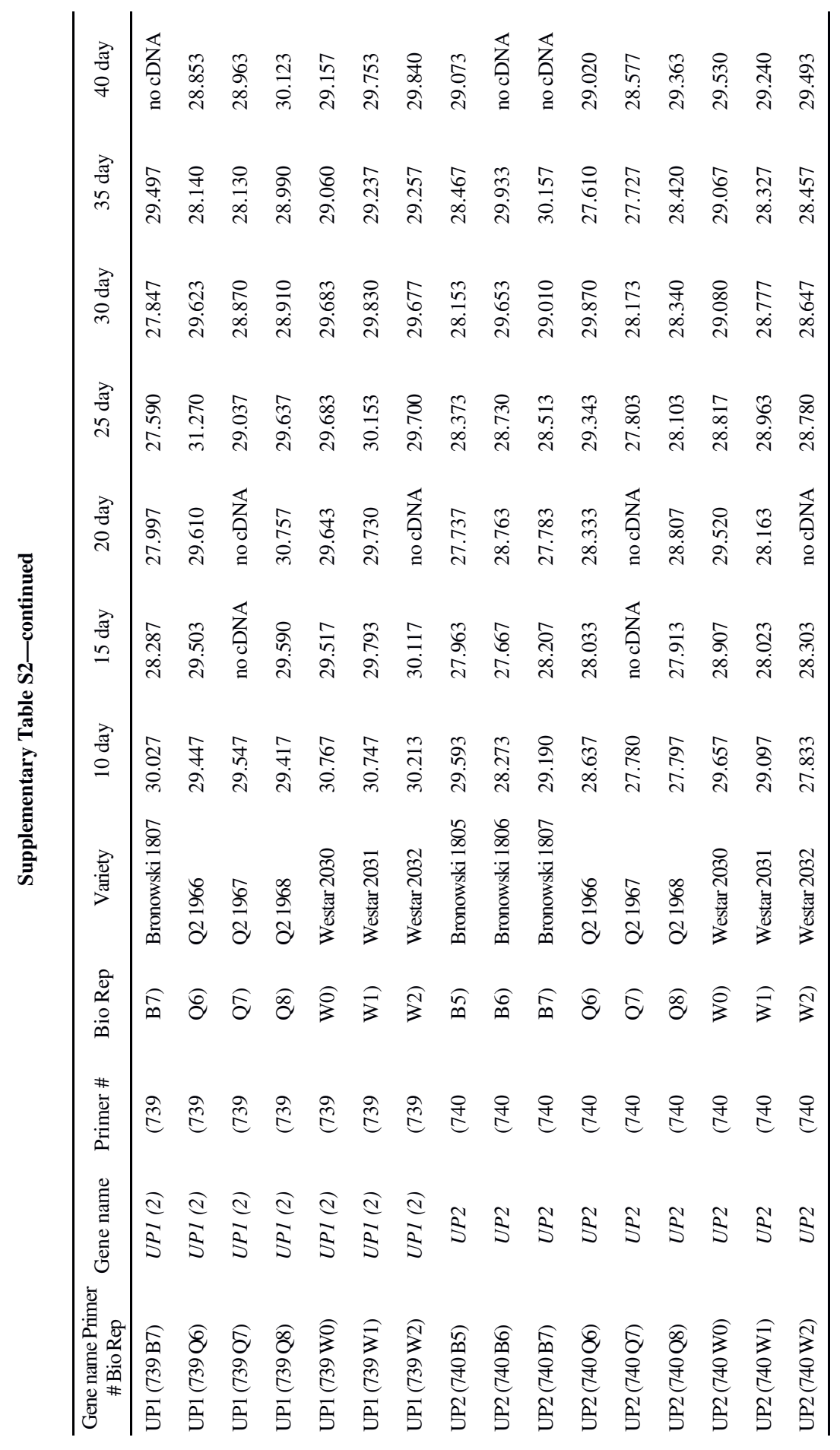




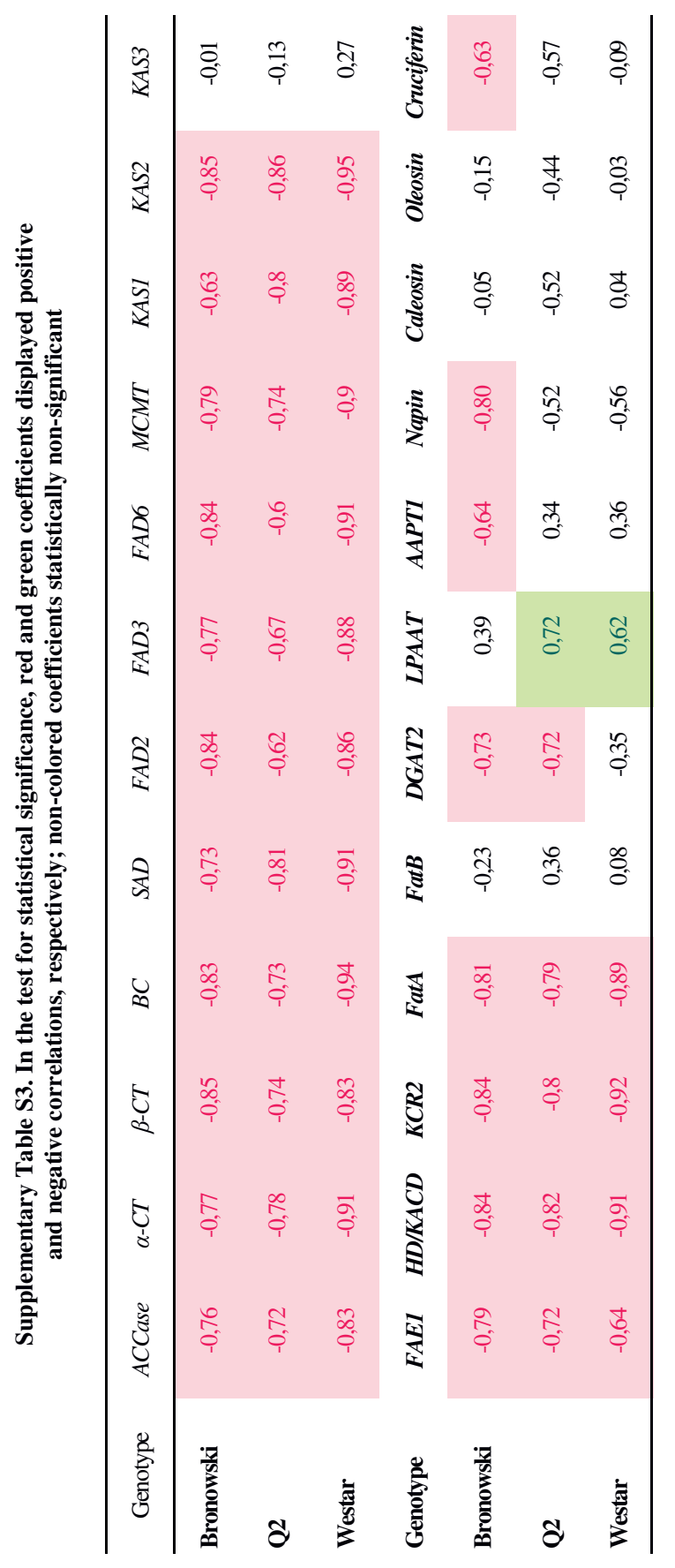

